\title{
New records of Parvalona parva (Crustacea: Anomopoda: Chydoridae) from Brazil, with first description of the male
}

\author{
Lourdes M.A. Elmoor-Loureiro ${ }^{1,4}$; Maria J. dos Santos-Wisniewski ${ }^{2} \&$ Odete Rocha ${ }^{3}$ \\ ${ }^{1}$ Laboratório de Zoologia, Universidade Católica de Brasília. QS 7 lote 1, Bloco M sala 331, 72030-170 Taguatinga, Distrito \\ Federal, Brasil. E mail: lourdes@ucb.br \\ ${ }^{2}$ Departamento de Ciencias Biológicas e da Terra, Universidade Federal de Alfenas. Alfenas, Minas Gerais, Brasil. \\ ${ }^{3}$ Departamento de Ecologia e Biologia Evolutiva, Universidade Federal de São Carlos, São Carlos, SP, Brasil. \\ ${ }^{4}$ Corresponding author.
}

\begin{abstract}
The Neotropical species Parvalona parva (Daday, 1905) was previously reported only from two localities (Northern Argentina and Lençóis Maranhenses, Brazil). In the present paper, seven new records of $P$. parva from Brazil are presented. The specimens were collected from small waterbodies located in the Federal District and the states of São Paulo, Pará, and Pernambuco. These new records suggest that this species is not as rare as previously believed. The male, sexual female, and the lateral head pores of parthenogenetic females are described and illustrated for the first time.
\end{abstract}

KEY WORDS. Aloninae; cladoceran; South America; systematic.

DADAY (1905) described Leydigia parva from Paraguay; later, this taxon was transferred to Alona Baird, 1843 (Smirnov, 1971). However, due to its unique characteristics, VAN DAMME et al. (2005) created the new genus Parvalona to allocate this species.

Until recently, the only known specimens of Parvalona parva (Daday, 1905) were those of Daday. VAN DAmme et al. (2005) reported a few parthenogenetic females from Lençóis Maranhenses, Northeast Brazil, and giving the scarcity of records, suggested that $P$. parva was a rare South American species. Nevertheless, the existence of these Brazilian records indicates that this taxon has a broader distribution than was previously thought. It also suggests that, at least partially, the lack of records could result from the poor knowledge on cladoceran fauna in South America.

The present paper presents new records of $P$. parva from Brazil and describes its male for the first time.

\section{MATERIAL AND METHODS}

The studied specimens were sampled from seven Brazilian sites (Fig. 1). Specimens were deposited at Laboratory of Zoology of the Catholic University of Brasília (access number in parenthesis) and in the collection of the Natural History Museum of the Federal University of São Carlos: four parthenogenetic females from Serra de Carajás, Pará State, 6 ${ }^{\circ} 24^{\prime} 30^{\prime \prime}$, $50^{\circ} 21^{\prime} 4$ "W, Paloma Lopes and Reinaldo L. Bozzelli leg. (EL00881); a parthenogenetic female from Apipucos reservoir, Recife, Pernambuco State, $\left.8^{\circ} 1^{\prime} 16^{\prime \prime} S, 34^{\circ} 55^{\prime} 59^{\prime \prime} \mathrm{W}\right)$, January $17^{\text {th }}, 2000$ (slide EL01541); a parthenogenetic female from Joaquim Medeiros Lagoon, Federal District, $15^{\circ} 38^{\prime} 16^{\prime \prime}$, 47 $41^{\circ} 30^{\prime \prime} \mathrm{W}$, August $8^{\text {th }}, 2006$ (EL00880); c. 20 parthenogenetic females from
Cedro Pond, Federal District, $15^{\circ} 53^{\prime} 50^{\prime \prime S}, 47^{\circ} 56^{\prime} 37^{\prime \prime} \mathrm{W}$, sampled in different occasions from October $9^{\text {th }}, 1989$ to April $3^{\text {rd }}, 2002$ (EL00876 to EL0879, slides EL01535 to EL01540); parthenogenetic females from a lake in Rio Paraná floodplain, UGRHI Aguapeí, $21^{\circ} 17^{\prime} 45^{\prime \prime}$ S, 51 $51^{\circ} 02^{\prime \prime} \mathrm{W}$, August, $14^{\text {th }} 2002$; parthenogenetic females from Japaris Reservoir, UGRHI Ribeira de Iguape, São Paulo state, $23^{\circ} 56^{\prime} 49^{\prime \prime}$ S, $47^{\circ} 30^{\prime} 09^{\prime \prime}$ W, August, $27^{\text {th }} 2001$; two parthenogenetic females, one sexual female, and two males from a pond at Aurora Farm, in UGRHI Mogi-Guaçu, São Paulo state, $20^{\circ} 59^{\prime} 49^{\prime \prime} \mathrm{S}, 47^{\circ} 58^{\prime} 57^{\prime \prime} \mathrm{W}$, December, $15^{\text {th }} 1999$ (EL00882, slides EL01542 to EL01544). Other individuals from this sample were also observed, including the juvenile male reported bellow, and deposited in the collection of the Natural History Museum of the Federal University of São Carlos.

The specimens from São Paulo were sampled during the project "Zooplankton biodiversity and state of degradation of continental water ecosystems in São Paulo state" within the program BIOTA FAPESP - The Virtual Institute of Biodiversity (www.biota.org.br); UGRHI - means Water Resources Management Unity.

Four adult females and two males were dissected for analysis of appendages. Enumeration of setae and other limb structures was done according to VAN DAMmE et al. (2005). Drawings were made with camera lucida.

\section{RESULTS}

The parthenogenetic females (Figs 2 and 8-16) fully agreed with the description presented by VAN DAMME et al. (2005). The observed denticles on the anterior outer portion of trunk limb I corm (Fig. 16), however, were more slender and longer than 


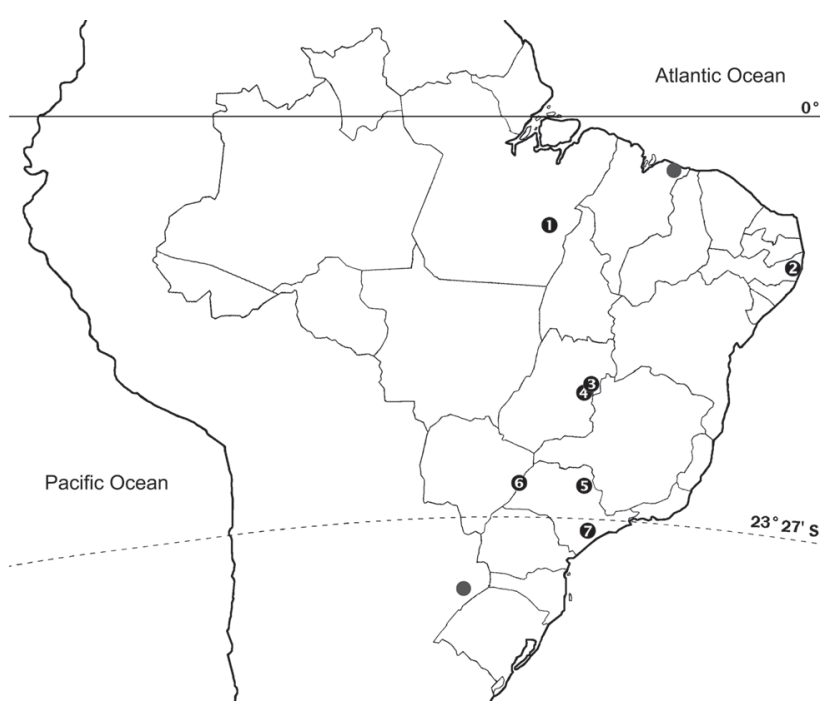

Figure 1. Distribution of Parvalona parva, showing previous (•) and present records, numbered as in text. (0) Serra dos Carajás, (2) Apipucos Reservoir, (3) Joaquim Medeiros Lagoon, (4) Cedro Pond, (5) pond at Aurora Farm, (6) central lagoon at Paraná River, (7) Japaris Reservoir.

those illustrated by these authors. The lateral head pores were observed and illustrated for the first time (Figs 14-15); they are punctiform and located at some distance from the median pores. The thin line around the median pores noted by VAN DAMme et al. (2005) was also observed in one specimen (Fig. 15).

The single ephippial female observed (Fig. 3) was similar to parthenogenetic females, in general aspects, except for the region of egg locule, which was pigmented, yellow-brown. No resting eggs were observed.

\section{Description of male}

Material studied: two males from a pond at Aurora Farm, in UGRHI Mogi-Guaçu, Brazil, sampled on December, $15^{\text {th }} 1999$, by M.J. Santos-Wisniewski (slide EL01542).

General (Fig. 17): similar to female in general view, but smaller (length about $370 \mu \mathrm{m}$ ).

Antennule (Fig. 19): short, not reaching tip of rostrum. There are 10 aesthetascs; the male seta arises subterminally, pointed, and about one third of the length of the antennule.

Antenna (Fig. 20): similar to the female one. Basal segment robust, with rudimentary distal spine and short setules at its distal margin. Antennal branches relatively elongated, all segments with rows of four to seven long setules. Antennal formula (exo/endo): setae 1-1-3/0-0-3, spines 0-0-1/1-0-1.

Mandible (Fig. 21): asymmetrical, elongate, with widened head bearing small ridges.

Trunk limb I (Figs 22-26): two ejector hooks of equal size. A series of long setules and groups of short denticles on the outer portion of limb corm. Gnathobase with a single short seta. ODL with a short, robust, naked seta, like a hook (in female, a long and slender seta); the rudimentary second seta present in female not seen. IDL of similar size to ODL, with two relatively short setae of similar size, less than twice the IDL length (in female, such setae are longer, about three times longer than IDL length - Fig. 16), armed with small setules unilaterally in terminal half. Endite 1 with three posterior soft setae (1-3), all armed with short hairs bilaterally, and one anterior seta (4) long, stout, with short setules in distal half. Endite 2 with three soft setae (5-7): seta 5 short, armed bilaterally with short setules, seta 6 longest, asymmetrically armed with long setules proximally, similar to seta 6 , but shorter; two small elements anterior to seta 5 . Endite 3 with three soft setae (8-10); seta 8 naked and significantly larger than setae 9 and 10, which are two-segmented, setulated along one side. With U-shaped copulatory hook, with two incisions (Fig. 23). Copulatory brush present; the longest seta about three times length of the small ones, and about half of male seta.

Trunk limb II (Fig. 27): exopodite a subovoid lobe with a row of setules. Eight scrapers, scrapers 1-3 with size slightly decreasing basally, scrapers 4 and 5 similar in size (in female, scraper 4 smaller than scraper 5), both smaller than scraper 3, scraper 5-8 decrease in size basally. As in females, a series of hillocks posteriorly to scrapers, gnathobase with prominent basal-ventral angle, with short setules, three gnathobasic elements, filter plate with six setae (two distalmost setae shorter).

Trunk limb III (Figs 28 and 29): as in females. Exopodite flat, relatively small, with five setae; setae 1 and 2 sparsely setulated with long filter setules exopodite; seta 3 is the longest and armed with long setules in distal half while proximal half bears shorter setules; seta 4 , bears short setules over complete length; seta 5 short and only setulated in distal half. Distal endite armed with three stiff setae. Basal endite, anteriorly with a sensillum and four, stiff setae; four posterior soft bilaterally setulated setae. Distal armature of gnathobase with four setae, the first of them a thick and large sensillum.

Trunk limb IV (Figs 30 and 31): as in females. Exopodite large, round, with six setae; setae 5 and 6 markedly smaller and slender than the others. Marginally on inner limb face, a row of four stiff setae, seta 1 longest, stout, naked, each of setae 2-4 armed with fine setules. Posteriorly, three soft setae. Distal armature of gnathobase with four elements. Filter plate with five similar setae.

Limb V (Fig. 32): as in females. Pre-epipodite small and setulated; epipodite ovoid. Exopodite large, ellipsoid, with four setae. Inner limb portion with wide flap-like distal projection, fringed by setules. Two submarginal setae.

Postabdomen (Fig. 18): postabdomen long and remarkably narrow distally; long postanal portion, about four times as long as preanal margin. Ventral margin straight. About 17 lateral fascicles, the five distal clearly longer than the others. Marginal denticles reduced. The spermoducts open ventral to 


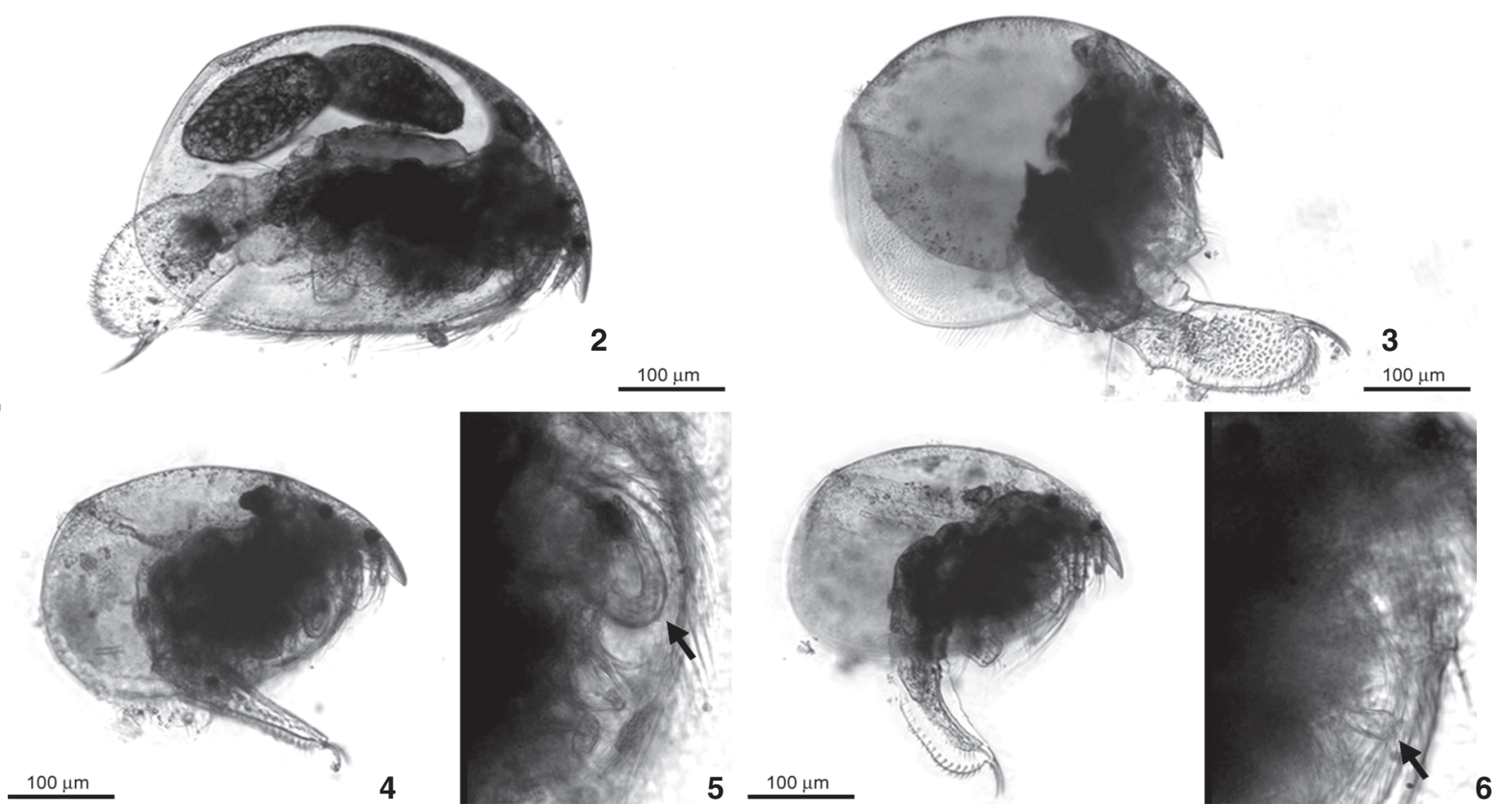

Figures 2-7. Parvalona parva, general aspect: (2) parthenogenetic female; (3) sexual female; (4) mature male; (5) mature male copulatory hook (arrow); (6) immature male; (7) rudimentar copulatory hook of immature male (arrow). Figure 2 from Cedro Pond; figures 3 7 from pond at Aurora Farm.

the base of the postabdominal claws, without any particular angle at margin.

Postabdominal claw (Fig. 18): curved (more than in female) and without basal spine.

\section{DISCUSSION}

An individual was observed showing both female and male characteristics (Figs 6-7): postabdomen similar to female ones, but slender and with spermoducts; trunk limb I with a rudimentar copulatory hook. According to SMIRnov (1967), chydorids combining male and female features represent young males. We believe that is the case here.

In comparison to females, in addition to the usual differences on trunk limb I (presence of the male seta and copulatory hook and brush seta), the males of $P$. parva also exhibit modifications in the IDL and ODL setae (Fig. 26). While these setae are long and slender in females (about three times the length of the lobes - Fig. 16), they are shorter and more robust in males, particularly the hook-like ODL seta. Reduction of IDL setae in males was also reported in the description of Alona brandorffi by Sinev \& Hollwedel (2002).

The present records are located within the known distribution of $P$. parva in South America, which ranges from Lençóis Maranhenses, in Northeast Brazil, to Argentina (Fig. 1). VAN DAMme et al. (2005), believed that the type locality "Curuzu- chica" is not in Paraguay, but equivalent to the Argentinian locality "Curuzú Cuatiá". However, there is another Argentinian locality named "Curuzú" $\left(27^{\circ} 55^{\prime} \mathrm{S}, 55^{\circ} 49^{\prime} \mathrm{W}\right)$, closer to the border Paraguay. We assumed the later locality to indicate Daday's record in figure 1 .

The males of $P$. parva here described were collected in a pond in Aurora Farm, located in Santa Cruz da Conceição municipality, São Paulo State. This is a small (200 m), shallow (1.5 m), transparent water body, with abundant macrophyte growth (Ludwigia sp., Cabomba sp., Nymphaea sp., and Scirpus sp.). At the sampling date the water body conditions were: $\mathrm{pH}$ 7.33; dissolved oxygen $7.31 \mathrm{mgl}^{-1}$, and water conductivity $59 \mu \mathrm{S}$.

The present records suggest that $P$. parva are not as rare as previously believed (VAN DAMME et al. 2005) and that more intense survey of South American water bodies is necessary to access its distribution. However, judging by the few specimens observed in each sample studied, this species is probably not abundant.

BERGAMIN (1939), based on samples from the state of São Paulo, illustrated a specimen identified as Birgeia travassosi Bergamin 1931, which was latter put on synonymy with Alona parva (Daday, 1905) (Smirnov, 1971). Elmoor-Loureiro (1997) questioned this synonymy and VAN DAMME et al. (2005) confirmed that it belongs to a different species. According to the latter authors, B. travassosi probably represents a young individual of a species of Leydigiopsis Sars, 1901. 


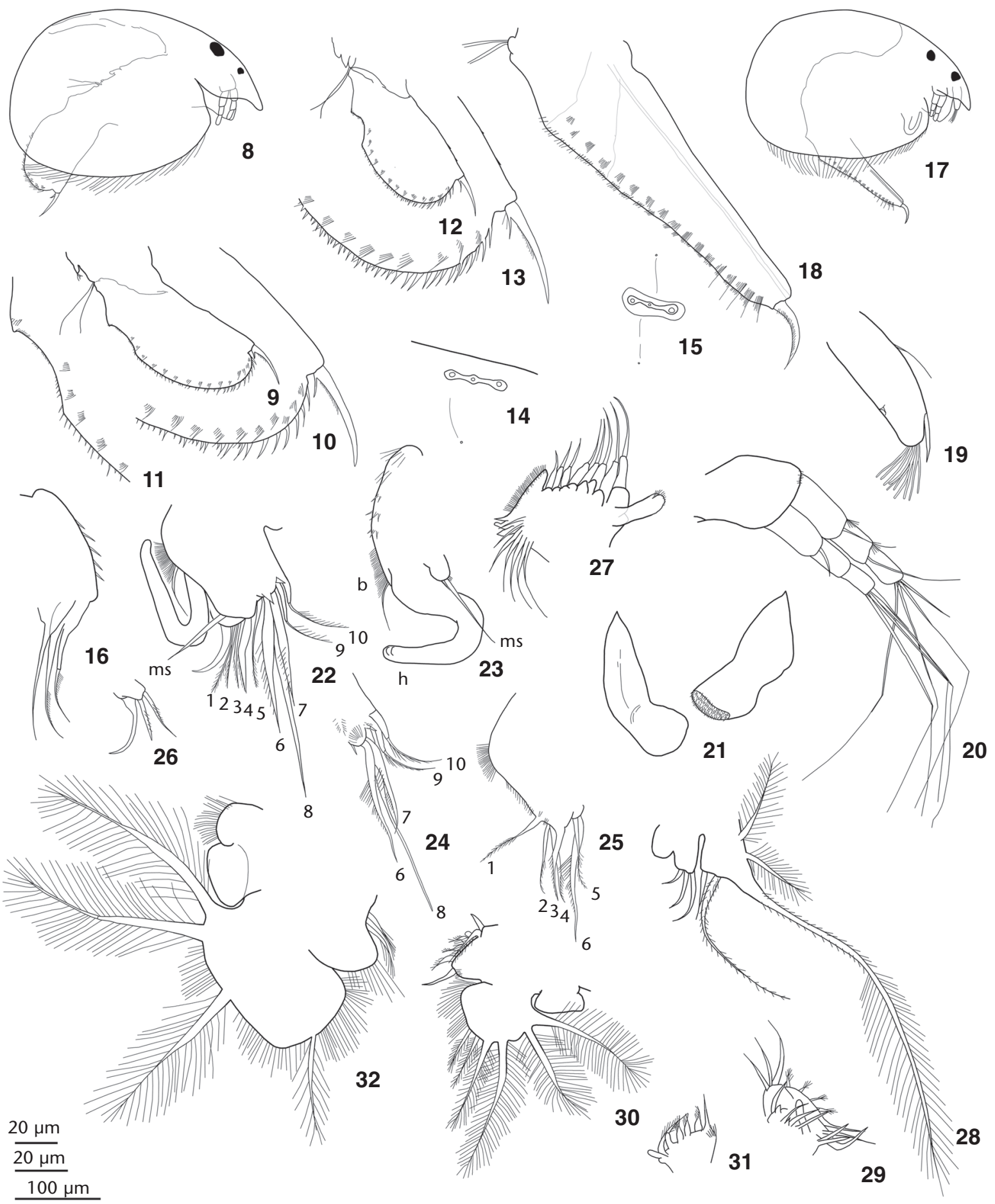

Figures 8-32. Parvalona parva: (8-16) parthenogenetic female; (8) general view: (9-13) postabdomen; (14-15) head pores; (16) IDL and ODL; (17-32) mature male: (17) general view; (18) postabdomen; (19) antennule; (20) antenna; (21) mandibles; (22) trunk limb I, general view; (23) trunk limb I, copulatory hook (h), brush (b), and male seta (ms); (24) trunk limb I, endite 1 and 2; (25) trunk limb I, endite 2 and 3; (26) IDL and ODL; (27) trunk limb II; (28) trunk limb III; (29) trunk limb III, endite; (30) trunk limb IV; (31) trunk limb IV, endite; (32) trunk limb V. Figures 8-11, 14-16 from Cedro Pond; figures 12-13, 17-32 from pond at Aurora Farm. 


\section{LITERATURE CITED}

Bergamin, F. 1939. Os Cladocera. Descrição sistemática das espécies encontradas no município de São Paulo. Revista de Indústria Animal, Nova Série, 2 (2): 80-86.

DADAY, E. 1905. Untersuchungen über die SüsswasserMikrofauna Paraguays. Zoologica 44: 1-375.

Elmoor-Loureiro, L.M.A. 1997. Manual de invertebrados límnicos do Brasil. Brasília, Editora Universa, 156p.

Sinev, A.Y. \& W. HollWEDEl. 2002. Alona brandorffi sp. nov. (Crustacea:
Anomopoda: Chydoridae) - a new species from Brazil, related to $A$. verrucosa Sars, 1901. Hydrobiologia 472: 131-140.

SMIRNov, N.N. 1967. On age morphological changes of males of Chydoridae (Cladocera). Hydrobiologia 30 (3-4): 555-571. SMIRNOV, N.N. 1971. Chydoridae of the world fauna, Fauna SSSR. Rakoobraznie 1 (2): 1-531.

Van Damme, K.; A.A. Kotov \& H.J. Dumont. 2005. Redescription of Leydigia parva Daday, 1905 and assignment to Parvalona gen. nov. (Cladocera: Anomopoda: Chydoridae). Journal of Natural History 39 (23): 2125-2136.

Submitted: 13.VII.2008; Accepted: 11.VI.2009.

Editorial responsability: Marcos D. S. Tavares 